\title{
The evolution of microstructure and electrical performance in doped Mn-Co and Cu-Mn oxide layers with the extended oxidation time
}

\author{
P.Y. Guo ${ }^{1}$, H. Sun ${ }^{1}$, Y. Shao ${ }^{1 *}$, J.T. Ding ${ }^{1}$, J.C. Li ${ }^{1}$, M.R. Huang ${ }^{1}$, S.Y. Mao ${ }^{1}$, Y.X. Wang ${ }^{1}$, J.F. Zhang ${ }^{2}$, R.C. Long ${ }^{3}$, \\ X.H. Hou ${ }^{4}$ \\ 1 School of Materials Science and Engineering, Jiangsu University of Science and Technology, Jiangsu 212003, China \\ 2 School of Electronics and Information Engineering, Suzhou Vocational University, Jiangsu 215104, China \\ 3 School of Foreign Studies, Yanshan University, Hebei 066004, China \\ 4 Faculty of Engineering, The University of Nottingham, Nottingham, NG7 2RD, UK
}

\begin{abstract}
Mn}-\mathrm{Co}$ and $\mathrm{Cu}-\mathrm{Mn}$ based alloy coatings are deposited on 430 SS by high energy micro-arc alloying process, and then alloy coatings are oxidized at $750{ }^{\circ} \mathrm{C}$ in air to form the spinel oxides. Some composite oxides, such as $\mathrm{Co}_{3} \mathrm{O}_{4}, \mathrm{Mn}_{2} \mathrm{O}_{3}$ and $(\mathrm{Mn}, \mathrm{Co})_{3} \mathrm{O}_{4}$, are formed at the initial stage of oxidation. The single-phase spinel (pure $\mathrm{MnCo}_{2} \mathrm{O}_{4}$ ) without impurity phases is only found on the surface of $\mathrm{Co}-33 \mathrm{Mn}-17 \mathrm{Cu}$ oxide layer with the extended oxidation time, its area-specific resistance values at $500{ }^{\circ} \mathrm{C}$ to $800{ }^{\circ} \mathrm{C}$ are low and close to that of $\mathrm{Mn}-35 \mathrm{Cu}$ oxide layer which mainly composed of $\mathrm{Cu}_{1.2} \mathrm{Mn}_{1.8} \mathrm{O}_{4}$ spinel.
\end{abstract}

Keywords: single-phase spinel; microcrystalline coating; high energy micro-arc alloying process; evolution 


\section{Introduction}

Besides the excellent high-temperature oxidation resistance, Mn-Co based spinel has the high conductivity and the appropriate coefficient of thermal expansion (CTE) matching the metallic interconnects and other components of solid oxide fuel cell (SOFC)[1-4]. To improve the properties and sintering ability, some active elements and transition metals have been doped into $\mathrm{Mn}-\mathrm{Co}$ based spinel, such as $\mathrm{Ce}, \mathrm{Ni}, \mathrm{Fe}$ or $\mathrm{Cu}$, which can modify the $\mathrm{CTE}$, enhance the densification and reduce the sintering temperature of $\mathrm{MnCo}_{2} \mathrm{O}_{4}[2,3]$.

The incorporation of active elements into alloy coatings will generally cause different effects on the high temperature oxidation behavior of coatings, such as enhancing the selective oxidation, changing the transformation mechanism, decreasing the growth rate of $\mathrm{Cr}_{2} \mathrm{O}_{3}$ at the substrate/coating interface, and improving the adhesion between oxide coating and substrate. When $\mathrm{NiFe}-\mathrm{CeO}_{2}$ alloy coatings are electrodeposited onto $430 \mathrm{SS}$ [5], the addition of $\mathrm{CeO}_{2}$ reduces the growth rate of $\mathrm{Cr}_{2} \mathrm{O}_{3}$ and the number of pores near the oxide/substrate interface, with a higher coating electrical conductivity. In another report, Co-38Mn-2Dy alloy layer is prepared by high energy micro-arc alloying process [6], and the addition of Dy effectively improves the oxide scale adhesion and decreases the oxidation rate of coating. Lanthanum (La) is a basic element in the traditional perovskite cathodes and interconnects of SOFC, so Mn-Co based spinel coatings with Lanthanum will also be an important research content in this work.

Cu-Mn metallic coatings [7] are deposited on SUS 430 via magnetron sputtering process. The results show that the converted $(\mathrm{Mn}, \mathrm{Cu})_{3} \mathrm{O}_{4} / \mathrm{CuO}$ oxide layers suppresses $\mathrm{Cr}$ outward diffusion and improves the electrical performance of metallic interconnects. $\mathrm{Cu}-\mathrm{Mn}$ spinel coatings[8] are also deposited by electrophoretic deposition process, followed by a thermo-mechanical treatment, and the coatings after oxidation have a dense layer near the oxide/substrate interface, a porous outer layer and a $\mathrm{CuO}$ layer on the coating surface. Owing to its high conductivity and the matched $\mathrm{CTE}$ with metallic interconnects, $\mathrm{Cu}-\mathrm{Mn}$ based spinel coatings are garnering the increasing attention compared to traditional Mn-Co based spinels $[9,10]$.

The expanded application of spinel coatings is now subjected to its poor adhesion, homogenization and densification. In recent attempts, the high-energy micro-arc alloying (HEMAA) process has been used to produce the metallurgically bonded alloy coatings which are then converted in-situ into spinel coatings by the thermal growth process [11-15]. Some reports have studied the oxidation behavior and electrical property of $\mathrm{LaCrO}_{3}$-based coatings, Mn-Co and Cr-La alloying layers deposited by the HEMAA process [16,17], confirming that the coating prepared by this process offers the excellent adhesion to the substrate and keeps low electrical contact resistance for the 
interconnects.

The single-phase Mn-Co or Cu-Mn based spinel without impurity phases is generally hard to form, even they are the calcined body synthesized by solid-state reaction, because some impurity oxide phases would be formed by the decomposition in the solid solution of cubic spinel $[18,19]$. Therefore, it becomes more difficult to prepare the pure single-phase spinel coatings, due to the phase diagram, restricted reaction temperature, pressure and other reaction conditions for metallic interconnects. In this experiment, $\mathrm{Cu}-\mathrm{Mn}, \mathrm{Mn}-\mathrm{Co}$ and $\mathrm{La} / \mathrm{Cu}$ doped $\mathrm{Mn}-\mathrm{Co}$ alloy coatings are deposited on 430 SS substrate by the HEMAA process. The microstructure and electrical performance of the alloy coatings with the extended oxidation time are discussed in details. This work aims to investigate the formation process of the pure single-phase spinel coatings, and elucidate the underlying mechanisms in such process.

\section{Experiments}

\subsection{Preparation of alloys and coatings}

Type 430 stainless steel is used as the substrate (cathodes for HEMAA process) and its nominal composition is 16-18 $\mathrm{Cr}, 1 \mathrm{Mn}, 0.12 \mathrm{C}, 0.75 \mathrm{Si}, 0.03 \mathrm{~S}, 0.06 \mathrm{Ni}, 0.04 \mathrm{P}$, and balance Fe (wt. \%). Alloy ingots of Co-33Mn-17Cu (Cu doped $\mathrm{Mn}-\mathrm{Co}$ ), $\mathrm{Mn}-35 \mathrm{Cu}, \mathrm{Co}-38 \mathrm{Mn}-2 \mathrm{La}$ (La doped $\mathrm{Mn}-\mathrm{Co}$ ) and Co-35Mn (at.\%) is pre-prepared by argon arc melting of high purity metals (99.99 wt.\%). The molar ratios of element $\mathrm{Cu} / \mathrm{Mn}$ and $\mathrm{Mn} / \mathrm{Co}$ in the alloys are designed to be between 1.0:2.0 and 1.5:2.0. The alloy ingots are cut into the specific rods as anodes for HEMAA process. The details for deposition process of alloy layers have been described in previously published articles [20-22].

\subsection{Oxidation experiment and area-specific resistance testing}

The thermal oxidation experiments are conducted at $750^{\circ} \mathrm{C}$ in air in a horizontal tube furnace (Hengli-CHLZG, Luoyang, China). The coated substrates are suspended ahead in the constant temperature zone of the furnace, and then the temperature gradually rises to $750^{\circ} \mathrm{C}$. After oxidation for $20 \mathrm{~h}, 100 \mathrm{~h}, 300 \mathrm{~h}$, and $500 \mathrm{~h}$, samples are respectively taken out from the furnace and directly cooled to room temperature (RT). The mass gain of samples is weighed at room temperature after cooling using an electronic balance with an accuracy of $0.01 \mathrm{mg}$.

The area-specific resistance (ASR) measurement of oxide layers is based on the four-probe DC method with the applied voltage $5 \mathrm{~V}$ and contact area $10 \mathrm{~mm}^{2}$ by Pt plate. Every setting temperature (per $100{ }^{\circ} \mathrm{C}$ from $500{ }^{\circ} \mathrm{C}-800{ }^{\circ} \mathrm{C}$ ) keeps stable for at least one hour for the accuracy of resistance reading [20-22]. 


\subsection{Microstructure analysis}

The phase structures of oxide scale on the surface are identified with X-ray diffraction (XRD) (D/MAX-3B, Rigaku Co., Tokyo, Japan). The oxidized samples are embedded into a cold-setting epoxy resin for the cross-section morphology analysis by scanning electron microscopy (SEM) (JSM-5800, JEOL, Tokyo, Japan). The surface morphology and elemental homogeneity in oxide layers are examined by SEM with energy dispersive X-ray spectroscopy (EDS).

\section{Results and Discussion}

\subsection{Evolution of oxide particle sizes}

Figure 1 shows the average particle size, minimum particle size and maximum particle size of spinel oxide for four alloy layers oxidized at $750^{\circ} \mathrm{C}$ in air for the different time. In the previous study[21, 22], Cu-Mn spinel size is larger than that of Mn-Co spinel, and Mn-Co spinel size is larger than that of Mn oxides and Co oxides after alloy layers oxidized at $750^{\circ} \mathrm{C}$ for $100 \mathrm{~h}$, which is also shown in Fig.1. Fig.1 a discloses that the average particle size of $\mathrm{Mn}-35 \mathrm{Cu}$ oxides is the largest among the oxide layers, and average particle size increases firstly then turns to decrease with the extended oxidation time. $\mathrm{Cu}$ doped $\mathrm{Mn}$-Co spinel is the second largest, and there is a slight increase in size after oxidation between $100 \mathrm{~h}$ and $500 \mathrm{~h}$. The average particle size of Co-35Mn oxide layer is small and close to that of La doped Mn-Co spinel which is the smallest in size. The results indicate that the doping of element La reduces the particle size of Mn-Co-base spinel, while the doping of element $\mathrm{Cu}$ increases the size. Fig. $1 \mathrm{~b}$ shows that the minimum particle size of $\mathrm{Cu}$ doped $\mathrm{Mn}$-Co spinel is the largest among the oxide layers and that of $\mathrm{Mn}-35 \mathrm{Cu}$ oxides is the smallest. Fig.1c discloses that the maximum grain sizes of Mn-Co-based oxides are slightly different, and that of $\mathrm{Mn}-35 \mathrm{Cu}$ oxides is much larger than the other three oxides when coatings oxidized for $100 \mathrm{~h}$ and $300 \mathrm{~h}$, which is mainly due to the formation and growth of $\mathrm{Cu}-\mathrm{Mn}$ spinel instead of Mn-Co spinel in Mn-Co-based oxides. There appears the significant fluctuation of particle size for $\mathrm{Mn}-35 \mathrm{Cu}$ oxides and the small fluctuation for $\mathrm{Cu}$ doped $\mathrm{Mn}-\mathrm{Co}$ oxides during the oxidation period of $500 \mathrm{~h}$.

\subsection{Evolution of oxidation products for $\mathrm{Cu}-\mathrm{Mn}$ layer and $\mathrm{Cu}$ doped $\mathrm{Mn}$-Co layer}

Figures 2 (a) and 2 (b) show the XRD spectra of $\mathrm{Mn}-35 \mathrm{Cu}$ alloy layer oxidized at $750^{\circ} \mathrm{C}$ for $20 \mathrm{~h}, 100 \mathrm{~h}, 300 \mathrm{~h}$ and $500 \mathrm{~h}$. The surface oxides of $\mathrm{Mn}-35 \mathrm{Cu}$ layer are mainly $\mathrm{Cu}_{1.2} \mathrm{Mn}_{1.8} \mathrm{O}_{4}$ spinel and $\mathrm{Mn}_{2} \mathrm{O}_{3}$ with a small amount of $\mathrm{Fe}_{2} \mathrm{O}_{3}$. The partial XRD analysis discloses that at the initial stage of oxidation $(20 \mathrm{~h})$ the characteristic diffraction peak intensity is week for both $\mathrm{Cu}_{1.2} \mathrm{Mn}_{1.8} \mathrm{O}_{4}$ and $\mathrm{Mn}_{2} \mathrm{O}_{3}$ and peak appears broad. When the oxidation time is extended to 
$100 \mathrm{~h}$, the intensity of $\mathrm{Mn}_{2} \mathrm{O}_{3}$ diffraction peak $\left(32.9^{\circ}, 38.2^{\circ}\right.$ and $\left.55.1^{\circ}\right)$ increases substantially with a sharp shape, and the $\mathrm{Cu}_{1.2} \mathrm{Mn}_{1.8} \mathrm{O}_{4}$ peak intensity also enhanced. The discussion of oxide products for $20 \mathrm{~h}$ and $100 \mathrm{~h}$ were shown in details in reference 22. At the oxidation time of $300 \mathrm{~h}$ and $500 \mathrm{~h}$, the intensity of the $\mathrm{Mn}_{2} \mathrm{O}_{3}$ diffraction peak is weaker compared to $100 \mathrm{~h}$, while the $\mathrm{Cu}_{1.2} \mathrm{Mn}_{1.8} \mathrm{O}_{4}$ peak intensity obviously increases such as the peaks of $30.2^{\circ}, 35.7^{\circ}, 57.4^{\circ}$ and 63.1 ${ }^{\circ}$. This indicates that a mass of stable $\mathrm{Cu}_{1.2} \mathrm{Mn}_{1.8} \mathrm{O}_{4}$ spinel phase is formed and $\mathrm{Mn}_{2} \mathrm{O}_{3}$ oxides reduce. The surface oxide phases become more uniform with the oxidation time increasing to $500 \mathrm{~h}$.

The XRD analysis of Co-33Mn-17Cu layer oxidized at different times is presented in Figs. 2 (c) and 2 (d). The oxide products oxidized for $20 \mathrm{~h}$ and $100 \mathrm{~h}$ are mainly the mixed oxides of $\mathrm{MnCo}_{2} \mathrm{O}_{4}$ spinel and $\mathrm{Mn}_{2} \mathrm{O}_{3}$. The magnification of the diffraction peak at $29^{\circ}-38^{\circ}$ shows that the characteristic peak of $\mathrm{MnCo}_{2} \mathrm{O}_{4}$ spinel is weak and relatively smooth (such as the peaks of $30.2^{\circ}$ and $35.9^{\circ}$ ) in the early stage of oxidation (before $100 \mathrm{~h}$ ), indicating that spinel gradually begins to form. Meanwhile, $\mathrm{Mn}_{2} \mathrm{O}_{3}$ diffraction peak is noticeable at the beginning (the peak of $32.9^{\circ}$ for $20 \mathrm{~h}$ ). The discussion of oxide products for $20 \mathrm{~h}$ and $100 \mathrm{~h}$ were shown in details in reference 21 .

When the oxidation time is extended to $300 \mathrm{~h}$, the surface oxides of $\mathrm{Co}-33 \mathrm{Mn}-17 \mathrm{Cu}$ layer tend to be a single-phase spinel structure. The peak intensity of $\mathrm{MnCo}_{2} \mathrm{O}_{4}$ spinel with a small quantity of $\mathrm{CuMn}_{2} \mathrm{O}_{4}$ is obviously enhanced in the range of $29^{\circ}-38^{\circ}$ in Fig.2(d). Meanwhile, the characteristic peak of $\mathrm{Mn}_{2} \mathrm{O}_{3}$ is greatly weakened. When the oxidation time reaches $500 \mathrm{~h}$, the characteristic peaks of non-spinel oxides disappear and there is only pure $\mathrm{MnCo}_{2} \mathrm{O}_{4}\left(\mathrm{CuMn}_{2} \mathrm{O}_{4}\right)$ spinel phase, which suggests that the extended oxidation time promotes the spinel growth in $\mathrm{Cu}$ doped Mn-Co layer. In addition, the characteristic peak at 500h shifts slightly to the left, mainly because the atomic ratios of $\mathrm{Mn} / \mathrm{Co}$ in spinel phases slightly change.

\subsection{Oxidation products for four coatings and 430 SS}

The oxide XRD peaks of $\mathrm{Mn}-35 \mathrm{Cu}, \mathrm{Co}-33 \mathrm{Mn}-17 \mathrm{Cu}, \mathrm{Co}-38 \mathrm{Mn}-2 \mathrm{La}$ and $\mathrm{Co}-35 \mathrm{Mn}$ layers after oxidation at $750^{\circ} \mathrm{C}$ for $500 \mathrm{~h}$ are the significantly different, as shown in Fig. 3(a) and 3(b). The main products of La doped Mn-Co layer and Co-35Mn layer oxidized for $500 \mathrm{~h}$ are $\mathrm{Mn}_{2} \mathrm{O}_{3}$ with some $(\mathrm{Mn}, \mathrm{Co})_{3} \mathrm{O}_{4}$ spinel which is an intermediate tetragonal spinel structure between $\mathrm{MnCo}_{2} \mathrm{O}_{4}$ (cubic) and $\mathrm{Mn}_{3} \mathrm{O}_{4}$ (tetragonal) [21]. The spinel diffraction peaks are not sharp and mainly exhibit non-spinel phase. $\mathrm{Cu}$ doped $\mathrm{Mn}$-Co layer only shows the sharp spinel oxide peaks. Meanwhile, $\mathrm{Mn}-35 \mathrm{Cu}$ layer shows the strong spinel peaks and strong $\mathrm{Mn}_{2} \mathrm{O}_{3}$ peaks, indicating the mixed oxides at room temperature. Fig. 3(c) shows XRD patterns of $430 \mathrm{SS}$ substrate oxidized at $750^{\circ} \mathrm{C}$ for $300 \mathrm{~h}$ and $500 \mathrm{~h}$, respectively. It can be seen that the surface oxides of $430 \mathrm{SS}$ are mainly $\mathrm{Mn}-\mathrm{Cr}$ spinel and $\mathrm{Cr}_{2} \mathrm{O}_{3}$. 


\subsection{Oxidation kinetic and morphology characteristics}

Oxidation kinetic curves of $\mathrm{Mn}-35 \mathrm{Cu}$ layer, $\mathrm{Co}-33 \mathrm{Mn}-17 \mathrm{Cu}$ layer and $430 \mathrm{SS}$ oxidized at $750{ }^{\circ} \mathrm{C}$ for $500 \mathrm{~h}$ are shown in Fig. 4. The previous published articles [21] propose that, after oxidation for $100 \mathrm{~h}$, the mass gains of the three oxide layers (Mn-Co and $\mathrm{La}$ or $\mathrm{Cu}$ doped $\mathrm{Mn}$-Co layers) change and follow the same tendency, so these data of Co-35Mn and Co-38Mn-2La layer is not shown in Fig. 4. The mass gain of $430 \mathrm{SS}$ is the smallest during the oxidation process and that of $\mathrm{Mn}-35 \mathrm{Cu}$ layers is the largest in the initial stage of $100 \mathrm{~h}$. The mass gains of $\mathrm{Mn}-35 \mathrm{Cu}$ and Co-33Mn-17Cu layers between $100 \mathrm{~h}$ and $500 \mathrm{~h}$ lightly change.

Surface morphology is presented for the coated $430 \mathrm{SS}$ after oxidation at $750{ }^{\circ} \mathrm{C}$ for $500 \mathrm{~h}$ in Fig.5. According to the reference [22], after oxidation for $100 \mathrm{~h}, \mathrm{Cu}_{1.2} \mathrm{Mn}_{1.8} \mathrm{O}_{4}$ spinel on the surface of $\mathrm{Mn}-35 \mathrm{Cu}$ oxide layer reveals large granules, while $\mathrm{Mn}_{2} \mathrm{O}_{3}$ is much smaller than the spinel. This is in accordance with maximum particle sizes and minimum particle sizes for $100 \mathrm{~h}$ in Fig.1. With the increasing oxidation time to $500 \mathrm{~h}$, the particle sizes gradually become uniform and large granules decrease. Fig.5a shows the typical oxide morphology on the surface of $\mathrm{Mn}-35 \mathrm{Cu}$ layer and only the small amount of tiny particles are found (area 1). Element concentration analysis by EDS discloses that the different areas have approximately the similar composition for element $\mathrm{Cu}$ and $\mathrm{Mn}$ shown in Table 1. Combined with XRD in Fig.2, The oxides are mainly composed of $\mathrm{Cu}_{1.2} \mathrm{Mn}_{1.8} \mathrm{O}_{4}$ spinel and some $\mathrm{Fe}$ is also detected on the surface of $\mathrm{Mn}-35 \mathrm{Cu}$ oxide layer.

The typical surface morphology of Co-33Mn-17Cu layer oxidized for $500 \mathrm{~h}$ is shown in Fig. $5 \mathrm{~b}_{1}$. The particle sizes relatively keep uniform during the oxidation process and $\mathrm{MnCo}_{2} \mathrm{O}_{4}$ spinel (cubic-shaped) gradually is formed in the initial stage of $20 \mathrm{~h}$ [21]. Morphology characteristics of $\mathrm{MnCo}_{2} \mathrm{O}_{4}$ spinel are similar to that of $\mathrm{Cu}_{1.2} \mathrm{Mn}_{1.8} \mathrm{O}_{4}$ on $\mathrm{Cu}-35 \mathrm{Mn}$ oxide layer, but $\mathrm{MnCo}_{2} \mathrm{O}_{4}$ has the more uniform particle size. Element concentration in Table 1 discloses that $\mathrm{Fe}$ content on surface of $\mathrm{Co}-33 \mathrm{Mn}-17 \mathrm{Cu}$ oxide layer is a little lower than that on $\mathrm{Cu}-35 \mathrm{Mn}$ oxide layer.

Surface morphology of Co-38Mn-2La and Co-35Mn oxide layer in Fig. $5 \mathrm{c}_{1}$ and Fig.5 $\mathrm{d}_{1}$ shows their particle sizes are relatively small. The previous study [21] shows their spinel oxides are mainly an intermediate tetragonal spinel after oxidation for $100 \mathrm{~h}$. With the increasing oxidation time to $500 \mathrm{~h}$, the oxides keep the mixed phase structure and spinel diffraction peaks are not significantly enhanced (Fig. 3a and Table 1). In addition, though the small particles on the surface after $100 \mathrm{~h}$ are rich in element Mn, analysed by EDS, small particles as revealed in area 3 and area 4 after 500 $\mathrm{h}$ are nearly the same composition with large particles.

Cross section of $\mathrm{Mn}-35 \mathrm{Cu}$ oxide layer after oxidation for $500 \mathrm{~h}$ (Fig.5 $\left.\mathrm{a}_{2}\right)$ shows some isolated pores distributing on 
the outer part of oxide layer, and these pores are also detected in the external oxides of Co-33Mn-17Cu layer (Fig. $\left.5 \mathrm{~b}_{2}\right)$. The reason is speculated that the formation of vast coarse $\mathrm{Cu}-\mathrm{Mn}$ grains leads to numerous pores formed at the grain boundaries, such as some micro-pores between grains on the surface in Fig.5a. The doping of $\mathrm{Cu}$ in $\mathrm{Mn}$-Co oxides makes the spinel particles enlarge, so that the number of micro-pores in $\mathrm{Co}-33 \mathrm{Mn}-17 \mathrm{Cu}$ oxide layer is much more

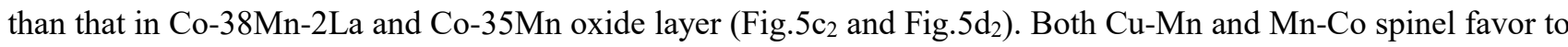
form in areas of high oxygen partial pressure, which explains some micro-pores mainly distribute on the outer oxide layer. In addition, the rapid diffusion of element $\mathrm{Cu}$ might also produce porous oxides[23].

The average thickness of four oxide layers is slightly different in Figs. $5 \mathrm{a}_{2}-\mathrm{d}_{2}$. We should note the thickness can be adjusted by the deposition parameters of HEMAA process [20]. Line scanning of EDS shows that the distribution of element $\mathrm{Co}, \mathrm{Mn}$ and $\mathrm{Cu}$ throughout the oxide layers is approximately uniform after $500 \mathrm{~h}$. $\mathrm{Cr}$ content is relatively low in the whole oxide layers and the $\mathrm{Cr}_{2} \mathrm{O}_{3}$ interface layers between the oxides and substrate are thin after oxidation for 500 h. Some Fe from $430 \mathrm{SS}$ substrate diffuses into the oxide layer, and the line scanning in Fig. $5 \mathrm{a}_{3}-\mathrm{d}_{3}$ shows that Fe content gradually decreases from oxide/substrate interface to the top surface, except for La doped Mn-Co layer. The single $\mathrm{CuMn}_{2} \mathrm{O}_{4} / \mathrm{MnCo}_{2} \mathrm{O}_{4}$ spinel phase in $\mathrm{Co}-33 \mathrm{Mn}-17 \mathrm{Cu}$ oxide layer is more effective to blocks the outward diffusion of Fe than the mixed oxides of Co-38Mn-2 La and Co-35Mn oxide layers, such as Fe content in Fig.5 $\mathrm{b}_{3}$.

\subsection{Evolution of ASR for Cu-Mn based and Mn-Co based oxide layers}

Figure 6(a) is the curves of ASR versus temperature in the range of $500{ }^{\circ} \mathrm{C}$ to $800{ }^{\circ} \mathrm{C}$ for the $\mathrm{Mn}-35 \mathrm{Cu}$ layer after oxidation at $750^{\circ} \mathrm{C}$ for the different time. It can be seen that all the ASR values at the four oxidation periods decrease with the increasing temperature in the range of $500{ }^{\circ} \mathrm{C}$ to $800{ }^{\circ} \mathrm{C}$. After the oxidation for $20 \mathrm{~h}$, ASR is remarkably higher than that of the other three oxidation periods, especially at $500{ }^{\circ} \mathrm{C}$ and $600{ }^{\circ} \mathrm{C}$. It might be because a large amount of mixed oxides which has the low electrical conductivity is formed at the early oxidation stage, such as $\mathrm{Mn}_{2} \mathrm{O}_{3}, \mathrm{Mn}_{3} \mathrm{O}_{4}$ and $\mathrm{CuO}$, resulting in a high ASR of the oxide film. With the prolongation of oxidation time, $\mathrm{Cu}$ ions have enough time to diffuse and react with $\mathrm{Mn}$ oxides to form $\mathrm{Cu}-\mathrm{Mn}$ spinel. In the meantime, the content of $\mathrm{Mn}_{2} \mathrm{O}_{3}$ oxides reduces, which improves the electrical conductivity of the whole oxide layer and leads to an obvious decline of ASR. After oxidation for $500 \mathrm{~h}$, ASR values of $\mathrm{Mn}-35 \mathrm{Cu}$ oxide layer is $33.8 \mathrm{~m} \Omega \cdot \mathrm{cm}^{2}$ for $500{ }^{\circ} \mathrm{C}, 18.8 \mathrm{~m} \Omega \cdot \mathrm{cm}^{2}$ for $600{ }^{\circ} \mathrm{C}, 8.1 \mathrm{~m} \Omega \cdot \mathrm{cm}^{2}$ for $700{ }^{\circ} \mathrm{C}$, and $74.1 \mathrm{~m} \Omega \cdot \mathrm{cm}^{2}$ for $800{ }^{\circ} \mathrm{C}$, respectively. Fig. 6(b) shows the Arrhenius plots of $\mathrm{ASR} / \mathrm{T}$ versus $10^{3} / \mathrm{T}$ for $\mathrm{Mn}-33 \mathrm{Cu}$ layer after oxidation. It is an accurate linear relationship between $\mathrm{Log}(\mathrm{ASR} / \mathrm{T})$ and $10^{3} / \mathrm{T}$, indicating the semiconductor characteristic of oxides formed on the substrate and the slopes of the lines decrease after oxidation for $100 \mathrm{~h}$. The ASR value is directly related to the high temperature behavior of thermally 
grown oxide layer, thus the oxides of $\mathrm{Mn}-35 \mathrm{Cu}$ coating after $500 \mathrm{~h}$ exhibits superior electrical conductivity between $500^{\circ} \mathrm{C}$ and $800^{\circ} \mathrm{C}$.

Figure 6(c) shows ASR values vs. temperature for $\mathrm{Cu}$ doped $\mathrm{Mn}$-Co layer oxidized at $750^{\circ} \mathrm{C}$ with the extended oxidation time. The relationship between ASR and oxidation time for $\mathrm{Cu}$ doped $\mathrm{Mn}$-Co layer shows the different evolution rules from that of $\mathrm{Mn}-35 \mathrm{Cu}$ layer. The highest resistance in the range of $500{ }^{\circ} \mathrm{C}$ to $800{ }^{\circ} \mathrm{C}$ is the value after oxidation for $100 \mathrm{~h}$, and the resistance rapidly decreases after $100 \mathrm{~h}$. The ASR values oxidized for $300 \mathrm{~h}$ and $500 \mathrm{~h}$ are almost the same, indicating that the characteristics of oxide layers in the two oxidation periods, such as the average thickness, oxide composition and the thickness of interface $\mathrm{Cr}_{2} \mathrm{O}_{3}$ layer, are almost the similar. The results of ASR are consistent with XRD and EDS analysis. According to cross-section analysis in Fig.5, Mn-35Cu layer oxidized for $500 \mathrm{~h}$ are porous and Fe content is relatively high in it, but the ASR values in Fig. 6(a) are still lower than that of $\mathrm{Cu}$ doped Mn-Co layer in Fig. 6(c), especially at $500{ }^{\circ} \mathrm{C}$ and $600{ }^{\circ} \mathrm{C}$.

ASR values at $800^{\circ} \mathrm{C}$ of four oxide layers and bared 430SS are shown in Fig. 7. The resistance of bared $430 \mathrm{SS}$ in 500 $\mathrm{h}$ of oxidation time is high and more than $100 \mathrm{~m} \Omega \cdot \mathrm{cm}^{2}$ in Fig. 7(a), except for $100 \mathrm{~h}$. The ASR values of four oxide layers shown in Fig. 7(b) all have a rapid increase in the initial stage of oxidation. The ASR at $800{ }^{\circ} \mathrm{C}$ of Co-35Mn layer and La doped Mn-Co layer continues to increase after $100 \mathrm{~h}$ shown in Fig. $7 \mathrm{~b}$ and the dopant of La obviously decreases the electrical resistance in the beginning. With the oxidation time increasing, the effect of La gradually reduces and the electrical resistance of the two oxide layers is close. The ASR at $800{ }^{\circ} \mathrm{C}$ of $\mathrm{Cu}$ doped Mn-Co layer and $\mathrm{Cu}-35 \mathrm{Mn}$ layer increases first, and then decreases. The peak value of $\mathrm{Cu}-35 \mathrm{Mn}$ oxides is about $18 \mathrm{~m} \Omega \cdot \mathrm{cm}^{2}$ at $20 \mathrm{~h}$, after which the values decrease slowly with the oxidation time. The peak value of $\mathrm{Co}-33 \mathrm{Mn}-17 \mathrm{Cu}$ oxides is about 41 $\mathrm{m} \Omega \cdot \mathrm{cm}^{2}$ at $100 \mathrm{~h}$, which is a bit higher than that of $\mathrm{Cu}-35 \mathrm{Mn}$ oxides. The electrical resistance sharply decreases after $100 \mathrm{~h}$, and then gently slows between $300 \mathrm{~h}$ and $500 \mathrm{~h}$. It is worth mentioning that $\mathrm{Cu}$ doped Mn-Co oxide layer exhibits the better electrical conductivity than Co-35Mn and Co-38Mn-2La oxide layers, and its value is close to that of $\mathrm{Cu}-\mathrm{Mn}$ spinel (electrical conductivity at $800{ }^{\circ} \mathrm{C}[24], \mathrm{MnCo}_{2} \mathrm{O}_{4} \sim 60 \mathrm{~S} \cdot \mathrm{cm}^{-1}$ and $\mathrm{Cu}_{1.2} \mathrm{Mn}_{1.8} \mathrm{O}_{4} \sim 225 \mathrm{~S} \cdot \mathrm{cm}^{-1}$ ). The ASR values at $800{ }^{\circ} \mathrm{C}$ are $4.2 \mathrm{~m} \Omega \cdot \mathrm{cm}^{2}$ for $\mathrm{Mn}-35 \mathrm{Cu}$ oxides and $7.7 \mathrm{~m} \Omega \cdot \mathrm{cm}^{2}$ for $\mathrm{Co}-33 \mathrm{Mn}-17 \mathrm{Cu}$ oxides after the oxidation for $500 \mathrm{~h}$.

\section{Discussions}

Schematic diagrams of formation process for the homogeneous oxides prepared by HEMAA are shown in Fig. 8 . There are four important steps described in the process of formation, and mass transport and microstructural 
evolution of alloy layers after oxidation are also discussed.

(1) Step 1, melting: The selected high purity metal pieces are melted and uniformly mixed to form an alloy of a given composition, which may be a solid solution (MnCo) or a two-phase or multi-phase structure[21,22].

(2) Step 2, HEMAA process: The alloys with some certain composition are deposited on the 430 SS substrate by HEMAA, which is a pulsed micro-welding technique with the instantaneous release of high current, resulting in a high cooling rate $\left(\sim 10^{6} \mathrm{Ks}^{-1}\right)$. The microcrystalline or even nanocrystalline alloy layers are obtained and metallurgically bonded to the $430 \mathrm{SS}$ substrate $[6,12,14,17,21,22]$.

(3) Step 3 oxidation $(0-100 \mathrm{~h})$ : The uniform microcrystalline coatings are oxidized at the SOFC operating temperature. The oxide products in the initial stage exhibit some multi-layer structures, and the element concentrations are uneven in each oxide layer [21,22].

(4) Step 4, oxidation (more than $300 \mathrm{~h}$ ): After the sufficient reaction time, oxide products are converted into the homogeneous oxide layers. The element concentrations in the oxide layer are gradually uniform, and the oxide products may be homogeneous, accompanied by the formation of the pure single-phase spinel $\left(\mathrm{MnCo}_{2} \mathrm{O}_{4} / \mathrm{CuMn}_{2} \mathrm{O}_{4}\right)$.

\subsection{Concentration control and composition uniformity}

The given concentrations and uniform composition of $\mathrm{Mn}-\mathrm{Co}$ and $\mathrm{Cu}-\mathrm{Mn}$ alloy layers are obtained by step 1 and step 2 in Fig. 8. The sintered bodies consisting of the single-phase spinel structure are usually synthesized by solid-state reaction method after the oxide powders were ball milled which is to achieve uniform crystallite size and better chemical homogeneity $[25,26]$. The temperature of solid-state reaction is generally above $1000{ }^{\circ} \mathrm{C}$. The temperature higher for the formation of pure spinel-type oxides [27,19]. Furthermore, multiple oxides may be generated after calcination instead of the single-phase spinel, if the powder concentration is not precisely controlled. Mn-Co-O phase diagram in air [28] shows a single-phase $\mathrm{MnCo}_{2} \mathrm{O}_{4}$ spinel would be formed between $600{ }^{\circ} \mathrm{C}$ and $900{ }^{\circ} \mathrm{C}$ (the operating temperatures of SOFC). When Mn concentration is more than $40 \%$, lots of Mn-rich oxides are formed, and when $\mathrm{Mn}$ concentration is less than $20 \%$, oxides are mainly $\mathrm{Co}_{3} \mathrm{O}_{4}$, which has been found in previous published articles $[16,20]$. Cu-Mn-O phase diagram[28] shows that $\mathrm{Cu}_{\mathrm{x}} \mathrm{Mn}_{3-\mathrm{x}} \mathrm{O}_{4}$ spinel may not be the pure phase at the operating temperatures of SOFC, because the atomic ratios of $\mathrm{Mn} / \mathrm{Co}$ need be precisely controlled with the temperature. According to Reference 31, pure $\mathrm{Cu}-\mathrm{Mn}$ spinel phase is formed at $850^{\circ} \mathrm{C}$, but $\mathrm{Mn}_{3} \mathrm{O}_{4}$ peaks appears when samples cooled down to room temperature. XRD in Fig. 2 shows that the $\mathrm{Mn}-35 \mathrm{Cu}$ coating oxidized for $300 \mathrm{~h}$ and $500 \mathrm{~h}$ is mainly $\mathrm{Cu}_{1.2} \mathrm{Mn}_{1.8} \mathrm{O}_{4}$ spinel with some $\mathrm{Mn}_{2} \mathrm{O}_{3}$, so it may be pure $\mathrm{Cu}_{1.2} \mathrm{Mn}_{1.8} \mathrm{O}_{4}$ spinel at high 
temperature, which will be discussed in the future. The concentration control and composition uniformity of Mn-Co and $\mathrm{Cu}-\mathrm{Mn}$ alloy coatings are critical to the subsequent formation of single-phase spinel. Some other methods of coating preparation, such as electrochemical deposition, plasma spraying and physical vapor deposition, are normally difficult to ensure both concentration accuracy and uniformity of element distribution in the coating, especially when the coatings contain high Mn content[29,30] and multiple elements [31-34].

\subsection{Grain refinement and metallurgical bonding}

The grain sizes of Mn-Co and $\mathrm{Cu}-\mathrm{Mn}$ alloy layers are much smaller than that of the corresponding cast alloys, which is owed to the rapid solidification of primary deposited particles during high energy micro-arc alloy process $[20,35,36]$. The effects of grain sizes on the high-temperature oxidation behavior have been extensively investigated, and it is generally believed that fine-grained alloys had much better high temperature performance than the coarse-grained alloys [37-39], such as oxide spallation reduced and thinner oxide layer formed on the fine-grained alloy. The common role of grain refinement in the oxidation of alloys is to enhance the diffusion of elements and accelerate phase transformation (the rapid formation of some oxides), because that the fine-grained structure may provide abundant grain boundaries, which has been found during the oxidation process of $\mathrm{Co}-33 \mathrm{Mn}-17 \mathrm{Cu}$ and $\mathrm{Mn}-35 \mathrm{Cu}$ alloy layers. The inward diffusion of oxygen in air is mainly along the grain boundary, and the microcrystalline structure of coatings promotes oxygen diffusion and increases the partial pressure of oxygen inside the coating. Metallurgical bonding between the alloy layer and 430SS substrate enhances interfacial bonding and restrains the growth of interfacial transition layer $\left(\mathrm{Cr}_{2} \mathrm{O}_{3}\right)$. Some other methods of coating preparation are normally difficult to make the coatings compact and metallurgical [2,40-42].

\subsection{Element doping and spinel types}

Some doped or substituted elements may suppress the decomposition of oxides and result in a more stable spinel structure for the oxides $[26,43,44]$. The crystal structure of the as-sintered Mn-Ni-Co oxides is a cubic spinel with a small amount of Ni-rich oxide phase, but no Ni-rich phase is detected in the Cr-substituted samples which is a single-phase of cubic spinel structure. The oxidation products of $\mathrm{Cu}$ doped Mn-Co layer after $300 \mathrm{~h}$ is the pure single-phase spinel but not for the other Mn-Co based layers. Structure and electrical properties of oxidation products are also greatly affected by spinel types. The grain size of $\mathrm{Cu}-\mathrm{Mn}$ spinel is generally large and some micro-pores is formed between the grain boundaries which is shown on the surface morphology and cross section (Fig.5 and Fig.8), especially for the initial oxidation stage [21,22]. The grain size of Mn-Co spinel is relatively small and uniform, and so there are few micro-pores in the oxides. The grain size of $\mathrm{Cu}$ doped $\mathrm{Mn}$-Co spinel is between the two kinds of 
oxides mentioned above and the micro-pores are a little smaller than $\mathrm{Cu}-\mathrm{Mn}$ spinel. $\mathrm{Cu}-\mathrm{Mn}$ spinel has better conductivity than Mn-Co spinel and the high Mn content will decrease the electrical conductivity Mn-Co spinel, such as $\mathrm{MnCo}_{2} \mathrm{O}_{4} 60 \mathrm{~S} \cdot \mathrm{cm}^{-1}, \mathrm{CoMn}_{2} \mathrm{O}_{4} 6.4 \mathrm{~S} \cdot \mathrm{cm}^{-1}$ and $\mathrm{Mn}_{3} \mathrm{O}_{4} 0.1 \mathrm{~S} \cdot \mathrm{cm}^{-1}$. The doping of $\mathrm{Cu}$ in $\mathrm{Mn}$-Co spinel accelerates the formation of Mn-Co spinel and promotes electrical conductivity. Additionally, when a small amount of Fe is doped in $\mathrm{Cu}-\mathrm{Mn}$ oxides, the porosity of oxides may reduce. Such as the micro-pores are mostly present in the outer part of oxides in Fig. $5\left(\mathrm{a}_{2}, \mathrm{~b}_{2}\right)$ and Fig. 8 where Fe content is lower than in the inner part of oxides.

\subsection{Control of the factors affecting thermal growth}

Besides the phase diagram, the oxygen activity, temperature, oxidation time and element concentrations all affect the thermal growth of spinel. According to previous research $[6,16,45]$, the ambient oxygen partial pressure at SOFC operating temperature $600^{\circ} \mathrm{C}-900^{\circ} \mathrm{C}$ will favor the formation of $\mathrm{Co}_{3} \mathrm{O}_{4}, \mathrm{CuO}, \mathrm{Mn}_{3} \mathrm{O}_{4}$ and $\mathrm{Fe}_{3} \mathrm{O}_{4}$, but the partial pressure of oxygen gradually decreases from air/oxide interface to oxide/substrate interface. The calculated values of oxygen partial pressure at equilibrium are $4.26 \times 10^{-3}$ atm for $\mathrm{Co}_{3} \mathrm{O}_{4}, 2.70 \times 10^{-6} \mathrm{~atm}$ for $\mathrm{CuO}, 4.69 \times 10^{-18} \mathrm{~atm}$ for $\mathrm{Fe}_{3} \mathrm{O}_{4}$ and $1.28 \times 10^{-25} \mathrm{~atm}$ for $\mathrm{Mn}_{3} \mathrm{O}_{4}$, and a higher value for the formation of $\mathrm{Cu}-\mathrm{Mn}$ and $\mathrm{Mn}-\mathrm{Co}$ spinels. In the beginning of oxidation, $\mathrm{Mn}$ and $\mathrm{Cu}$ in the coating rapidly diffuse outward to the surface, and Co diffuses outward and also inward into the substrate $[45,33] . \mathrm{Cr}_{2} \mathrm{O}_{3}$ is formed at oxide/substrate interface, some mixed oxides, such as $\mathrm{MnO}$, $\mathrm{Mn}_{3} \mathrm{O}_{4}, \mathrm{Fe}_{3} \mathrm{O}_{4}$ and $\mathrm{CoO}$, are also formed at the initial stage of oxidation. Mn-Co spinel oxides first dispersedly precipitate along grain boundaries of mixed oxides and then evolve into a continuous spinel oxide layer. Therefore, a continuous $\mathrm{Mn}$-Co or $\mathrm{Cu}-\mathrm{Mn}$ spinel oxide layer may be formed in the outer part of oxide layer because of the relatively high oxygen activity and the extended oxidation time. In step 3, when the four alloy layers are oxidized for $100 \mathrm{~h},(\mathrm{Co}, \mathrm{Mn})_{3} \mathrm{O}_{4}$ spinel, Co-rich oxides and $\mathrm{Mn}$-rich oxides are found in the oxide layer, respectively. These data is discussed in detail in previous studies (reference 21 and 22). In step 4, a homogeneous oxide layer is found after $500 \mathrm{~h}$. There is no element aggregation in the whole oxide layers, and Co-rich oxides and Mn-rich oxides are not found, yet. The single-phase $\mathrm{MnCo}_{2} \mathrm{O}_{4}$ is formed on the surface of Co- $33 \mathrm{Mn}-17 \mathrm{Cu}$ coating and $\mathrm{Cu}_{1.2} \mathrm{Mn}_{1.8} \mathrm{O}_{4}$ is the main oxide products on the surface of $\mathrm{Cu}-35 \mathrm{Mn}$ coating.

\section{Conclusions}

Co-33Mn-17Cu, Mn-35Cu, Co-38Mn-2La and Co-35Mn alloy layers have been prepared by HEMAA process. The evolution of oxide particle sizes on the surface shows that $\mathrm{Mn}-35 \mathrm{Cu}$ oxides have both the largest and smallest particles among the four oxide layers and particles tend to be uniform in size after $500 \mathrm{~h}$. Particle sizes of 
Co-33Mn-17Cu oxide layer slightly increase during the oxidation period of $500 \mathrm{~h}$. The evolution of oxidation products after $500 \mathrm{~h}$ shows that $\mathrm{Mn}-35 \mathrm{Cu}$ oxides correlate to $\mathrm{Cu}_{1.2} \mathrm{Mn}_{1.8} \mathrm{O}_{4}$ spinel with $\mathrm{Mn}_{2} \mathrm{O}_{3}$ and $\mathrm{Co}-33 \mathrm{Mn}-17 \mathrm{Cu}$ oxides are only $\mathrm{MnCo}_{2} \mathrm{O}_{4}$ spinel, while $\mathrm{Co}-38 \mathrm{Mn}-2 \mathrm{La}$ and $\mathrm{Co}-35 \mathrm{Mn}$ oxides correlate to $\mathrm{Mn}_{2} \mathrm{O}_{3}$ and $(\mathrm{Mn}, \mathrm{Co})_{3} \mathrm{O}_{4}$ spinel. The evolution of ASR values shows that the resistance of $\mathrm{Co}-33 \mathrm{Mn}-17 \mathrm{Cu}$ and $\mathrm{Mn}-35 \mathrm{Cu}$ oxides increases first and then decreases, but the resistance of Co-38Mn-2La and Co-35Mn oxides continues to increase after $100 \mathrm{~h}$. The ASR values at $800^{\circ} \mathrm{C}$ are $4.2 \mathrm{~m} \Omega \cdot \mathrm{cm}^{2}$ for $\mathrm{Mn}-35 \mathrm{Cu}$ oxides and $7.7 \mathrm{~m} \Omega \cdot \mathrm{cm}^{2}$ for $\mathrm{Co}-33 \mathrm{Mn}-17 \mathrm{Cu}$ oxides after oxidation for $500 \mathrm{~h}$. The formation process of the homogeneous oxide layers (pure single-phase $\mathrm{MnCo}_{2} \mathrm{O}_{4} \mathrm{spinel}_{\text {) }}$ is affected by many factors, such as the given concentrations and uniform composition of alloy layers, grain refinement and metallurgical bonding to the substrate, element doping and the types of spinel oxidized, the oxidation temperature and time, etc.. The pure single-phase spinel without impurity phases is only found on Co-33Mn-17Cu oxide layer after oxidation at $750{ }^{\circ} \mathrm{C}$ for $500 \mathrm{~h}$.

\section{Acknowledgments:}

This work was financially supported by China Scholarship Fund (2017), National Natural Science Foundation of China (51801077, 51201073), Research Fund of Jiangsu University of Science and Technology (1624821607-5)

\section{Reference}

[1] M. Bednarz, S. Molin, M. Bobruk, M. Stygar, E. Długoń, M. Sitarz, T. Brylewski. High-temperature oxidation of the Crofer $22 \mathrm{H}$ ferritic steel with $\mathrm{Mn}_{1.45} \mathrm{Co}_{1.45} \mathrm{Fe}_{0.1} \mathrm{O}_{4}$ and $\mathrm{Mn}_{1.5} \mathrm{Co}_{1.5} \mathrm{O}_{4}$ spinel coatings under thermal cycling conditions and its properties. Mater. Chem. Phys. 225 (2019) 227-238

[2] B. Talic, S.Molin, K. Wiik, P.V. Hendriksen, H.L. Lein. Comparison of iron and copper doped manganese cobalt spinel oxides as protective coatings for solid oxide fuel cell interconnects. J. Power Sources 372 (2017) 145-156

[3] S. Molin, P. Jasinski, L. Mikkelsen, W. Zhang, M. Chen, P.V. Hendriksen. Low temperature processed $\mathrm{MnCo}_{2} \mathrm{O}_{4}$ and $\mathrm{MnCo}_{1.8} \mathrm{Fe}_{0.2} \mathrm{O}_{4}$ as effective protective coatings for solid oxide fuel cell interconnects at $750^{\circ} \mathrm{C}$. J. Power Sources 336 (2016) 408-418

[4] Y.M. Liao, B. Zhang, M.H. Chen, M. Feng, J.l. Wang, S.L. Zhu, F.H. Wang, Self-healing metal-enamel composite coating and its protection for TiAl alloy against oxidation under thermal shock in $\mathrm{NaCl}$ solution. Corros. Sci. 167 (2020) 10852

[5] P.F. You, X. Zhang, H.L. Zhan, H.J. Liu, C.L. Zeng. Effect of $\mathrm{CeO}_{2}$ on oxidation and electrical behaviors of 
ferritic stainless steel interconnects with Ni-Fe coatings. Int. J. Hydrogen Energ. 43(2018)7492-7500

[6] Y.B. Lai, P.Y. Guo, Y. Shao,Y. Zhang, N. Liu. The role of Dy doping on oxidation behavior of Co-40Mn/Co coating for solid oxide fuel cell metal interconnects. J. Alloy. Compd. 694 (2017) 383-393

[7] S.J. Geng, Q.Q. Zhao, Y.H. Li, J.J. Mu, G. Chen, F.H. Wang, S.L. Zhu. Sputtered MnCu metallic coating on ferritic stainless steel for solid oxide fuel cell interconnects application. Int. J. Hydrogen Energ. 42(2017)10298-10307.

[8] Z.H. Sun, S. Gopalan, U.B. Pal, S.N. Basu. $\mathrm{Cu}_{1.3} \mathrm{Mn}_{1.7} \mathrm{O}_{4}$ spinel coatings deposited by electrophoretic deposition on Crofer 22 APU substrates for solid oxide fuel cell applications. Surf. Coat. Tech. 323 (2017) 49-57

[9] S.Y Zhen, W. Sun, P.Q, Li, G.Z, Tang, D. Rooney, K.N. Sun, X.X. Ma, High performance cobalt-free $\mathrm{Cu}_{1.4} \mathrm{Mn}_{1.6} \mathrm{O}_{4}$ spinel oxide as an intermediate temperature solid oxide fuel cell cathode. J. of Power Sources 315 (2016) $140-144$

[10] S. Joshi, A. Petric. Nickel substituted $\mathrm{CuMn}_{2} \mathrm{O}_{4}$ spinel coatings for solid oxide fuel cell interconnects. Int. J. Hydrogen Energ. 42 (2017) 5584-5589

[11] Ph.V. K. Korneev, A.N. Sheveyko, N.V. Shvindina, E.A. Levashov, D.V. Shtansky. Comparative study of Ti-C-Ni-Al, Ti-C-Ni-Fe, and Ti-C-Ni-Al/Ti-C-Ni-Fe coatings produced by magnetron sputtering, electro-spark deposition, and a combined two-step process. Ceram. Int. 44 (2018) 7637-7646

[12] P.Y. Guo, C.L. Zeng, N. Wang, Y. Shao. FeAl-based coatings deposited by high-energy micro-arc alloying process for wet-seal areas of molten carbonate fuel cell. J. Power Sources, 217 (2012) 485-490

[13] X. Wei, Z.G. Chen, J. Zhong, L. Wang, Z.W. Hou, Y. Zhang, F.L. Tan. Facile preparation of nanocrystalline Fe2B coating by direct electrospark deposition of coarse-grained Fe2B electrode material. J. Alloy. Compd. 717 (2017) $31-40$

[14] P.Y. Guo, Y. Shao, C.L. Zeng, M.F. Wu, W.L. Li. Oxidation characterization of FeAl coated 316 stainless steel interconnects by high-energy micro-arc alloying technique for SOFC. Mater Lett. 65 (2011) 3180-3183

[15] L.L. Yang, M.H. Chen, J.L. Wang, Y.X. Qiao, P.Y. Guo, S.L. Zhu, F.H. Wang, Microstructure and composition evolution of a single-crystal superalloy caused by elements interdiffusion with an overlay NiCrAlY coating on oxidation, J. Mater. Sci. Technol. 45(2020) 49-58, 
[16] Y.B. Lai, P.Y .Guo, Y. Shao, P.J. Tang, Y. Zhang, J.F. Zhang. Formation and performances of spinel reaction layers on Co-40Mn coatings under an oxygen pressure of $10^{5} \mathrm{~Pa}$ for solid oxide fuel cell interconnect application.Vacuum.130 (2016) 14-24

[17] Z.J. Feng, C.L. Zeng. Oxidation behavior and electrical property of ferritic stainless steel interconnects with a Cr-La alloying layer by high-energy micro-arc alloying process. J. Power Sources, 195(2010) 7370-7374

[18] K. Park, I.H. Han. Effect of $\mathrm{Cr}_{2} \mathrm{O}_{3}$ addition on the microstructure and electrical properties of Mn-Ni-Co oxides NTC thermistors. J. Electroceram. (2006) 17:1069-1073

[19] T. Yokoyama, A. Yamazaki, T. Meguro, D. Ito, Y. Koshiba, S. Okazaki. Preparation and electrical properties of sintered bodies composed of $\mathrm{Mn}_{(2.25-\mathrm{X})} \mathrm{Fe}_{\mathrm{X}} \mathrm{Ni}_{0.75} \mathrm{O}_{4}(0 \leqq \mathrm{X} \leqq 2.25)$ with cubic spinel structure. J. Electroceram. (2016) 37:151-157

[20] Y. Zhang, P.Y. Guo, Y. Shao, Y.B. Lai, J.Q. Zhang. Preparation and high-temperature performance of Co-10Mn and Co-40Mn alloy coatings for solid oxide fuel cell metal interconnects. J. Alloy. Compd. 680 (2016) 685-693

[21] P.Y. Guo, Y.B. Lai, Y. Shao, Y. Zhang, H.Sun, Y.X. Wang. Oxidation characteristics and electrical properties of doped Mn-Co spinel reaction layer for solid oxide fuel cell metal interconnects. Coatings, 8(2018) 42-53

[22] P.Y. Guo, Y.B. Lai, Y. Shao, Y. Zhang, Y.X. Wang. Thermal growth of $\mathrm{Cu}_{1.2} \mathrm{Mn}_{1.8} \mathrm{O}_{4}$ spinel coatings on metal interconnects for solid oxide fuel cell applications. Metals, 7(2017)522-532

[23] Q.X. Fu, F. Tietz, D. Sebold, E. Wessel, H.P. Buchkremer, Magnetron-sputtered cobalt-based protective coatings on ferritic steels for solid oxide fuel cell interconnect applications. Corros. Sci. 2012, 54, 68-76.

[24] N. Shaigan, W. Qu, D.G. Ivey, W.X. Chen. A review of recent progress in coatings, surface modifications and alloy developments for solid oxide fuel cell ferritic stainless steel interconnects. J. Power Sources, 195(2010)1529-1542

[25] J.M. Varghese, A. Seema, K.R. Dayas. Ni-Mn-Fe-Cr-O negative temperature coefficient thermistor compositions: Correlation between processing conditions and electrical characteristics. J. Electroceram. (2009) $22: 436-441$

[26] Q. Wang, W. Kong, J.C. Yao, A.M. Chang. Fabrication and electrical properties of the fast response $\mathrm{Mn}_{1.2} \mathrm{Co}_{1.5} \mathrm{Ni}_{0.3} \mathrm{O}_{4}$ miniature NTC chip thermistors. Ceram. Int. 45 (2019) 378-383 
[27] P.P. Deepak, M.Parokkaran, K.R. Ranjith, M.N. Muralidharan, S. Ansari. Optimization studies on nanocrystalline NTC thermistor compositions by a self-propagated high temperature synthesis route. Ceram. Int. 44 (2018) 4360-4366

[28] M.R. Bateni, P. Wei, X.H. Deng, A. Petric. Spinel coatings for UNS 430 stainless steel interconnects. Surface \& Coatings Technology 201 (2007) 4677-4684

[29] S. Apelt, Y. Zhang, J.H. Zhu, C. Leyens. Electrodeposition of Co- $\mathrm{Mn}_{3} \mathrm{O}_{4}$ composite coatings. Surf. Coat. Tech. 280 (2015) 208-215

[30] J. Puranen a, M. Pihlatie, J. Lagerbom, G. Bolelli, J. Laakso, L. Hyvarinen, M. Kylmalahti, O. Himanen, J. Kiviaho, L.Lusvarghi, P. Vuoristo. Post-mortem evaluation of oxidized atmospheric plasma sprayed Mn-Co-Fe oxide spinel coatings on SOFC interconnectors. Int. J. Hydrogen Energ. 39(2014)17284-17294

[31] Z.H. Sun, R.F. Wang, A.Y. Nikiforov, S. Gopalana, U.B. Pala. Soumendra N. Basua CuMn ${ }_{1.8} \mathrm{O}_{4}$ protective coatings on metallic interconnects for prevention of Cr-poisoning in solid oxide fuel cells. J. Power Sources 378 (2018) 125-133

[32] S.I. Castañeda, F.J. Pérez. Al-Mn CVD-FBR coating on $\mathrm{P} 92$ steel as protection against steam oxidation at $650^{\circ} \mathrm{C}$ : TGA-MS study. J. Nucl. Mater. 499 (2018) 419-430

[33] Y. Shao, P.Y. Guo, H.Sun, T.C. Zhou, J.T. Ding, K.X. Xu, Y.X. Wang, Y.X. Guo, D.P. Wang, X.H. Hou. Structure and properties of composite $\mathrm{Ni}-\mathrm{Co}-\mathrm{Mn}$ coatings on metal interconnects by electrodeposition. J. Alloy. Compd. $811(2019) 152006$

[34] Y.Z. Hu, S.W. Yao, C.X. Li, C.J. Li, S.L. Zhang. Influence of pre-reduction on microstructure homogeneity and electrical properties of APS $\mathrm{Mn}_{1.5} \mathrm{Co}_{1.5} \mathrm{O}_{4}$ coatings for SOFC interconnects. Int. J. Hydrogen Energ. 42(2017)27241-27253

[35] D.W. Heard, M. Brochu. Development of a nanostructure microstructure in the Al-Ni system using the electrospark deposition process. Journal of Materials Processing Technology, 210(2010)892-898

[36] W.F. Wang, M.C.Wang, F.J. Sun, Y.G. Zheng, J.M. Jiao. Microstructure and cavitation erosion characteristics of Al-Si alloy coating prepared by electrospark deposition. Surf. Coat. Tech. 2008, 202:5116 -5121

[37] X. Wang, J.A. Szpunar. Effects of grain sizes on the oxidation behavior of Ni-based alloy 230 and N. J. Alloy. 
Compd. 752 (2018) 40-52

[38] W. Peng, J Wang, H.W. Zhang, X.Y. Hong, Z.Y. Wu, Y.L. Xu, J. Lia, X.S. Xiao. Insights into the role of grain refinement on high-temperature initial oxidation phase transformation and oxides evolution in high aluminium Fe-Mn-Al-C duplex lightweight steel. Corros. Sci.126 (2017) 197-207

[39] X. Peng, J. Yan, Y. Zhou, F. Wang. Effect of grain refinement on the resistance of 304 stainless steel to breakaway oxidation in wet air. Acta. Mater. 53(2005) 5079-5088

[40] J. Li, C.Y. Xiong, J. Li, D. Yan, J. Pu, B. Chi, L. Jian. Investigation of $\mathrm{MnCu}_{0.5} \mathrm{Co}_{1.5} \mathrm{O}_{4}$ spinel coated SUS430 interconnect alloy for preventing chromium vaporization in intermediate temperature solid oxide fuel cell. Int. J. Hydrogen Energ. 42(2017) 16752-16759

[41] Y.X. Wang, D. Cao, W.D. Gao, Y.X. Qiao, Y.X. Jin, G. Cheng, W. Gao, Microstructure and properties of sol-enhanced Co-P-TiO 2 nano-composite coatings, J. Alloy. Compd., 792(2019)617-625.

[42] Q.Q. Zhao, S.J. Geng, G. Chen, F.H. Wang. Application of sputtered $\mathrm{NiFe}_{2}$ alloy coating for SOFC interconnect steel. J. Alloy. Compd. 769 (2018) 120-129

[43] K. Park, I.H. Han. Effect of $\mathrm{Cr}_{2} \mathrm{O}_{3}$ addition on the microstructure and electrical properties of Mn-Ni-Co oxides NTC thermistors. J. Electroceram. 17 (2006) 1069-1073

[44] H.M.T. Farid, I. Ahmad, I.Ali, S.M. Ramay, A. Mahmood. Study of spinel ferrites with addition of small amount of metallic elements. J. Electroceram. 42 (2019) 57-66

[45] F. Gesmundo, P. Nanni, D.P. Whittle. High temperature oxidation of Mn-Co alloys, Corros. Sci. 19(1979)675-691

[46] H. Zhang, J.W. Wu, X.B. Liu, A. Baker. Studies on elements diffusion of Mn/Co coated ferritic stainless steel for solid oxide fuel cell interconnects application. Int. J. Hydrogen Energ. 38(2013)5075-5083 

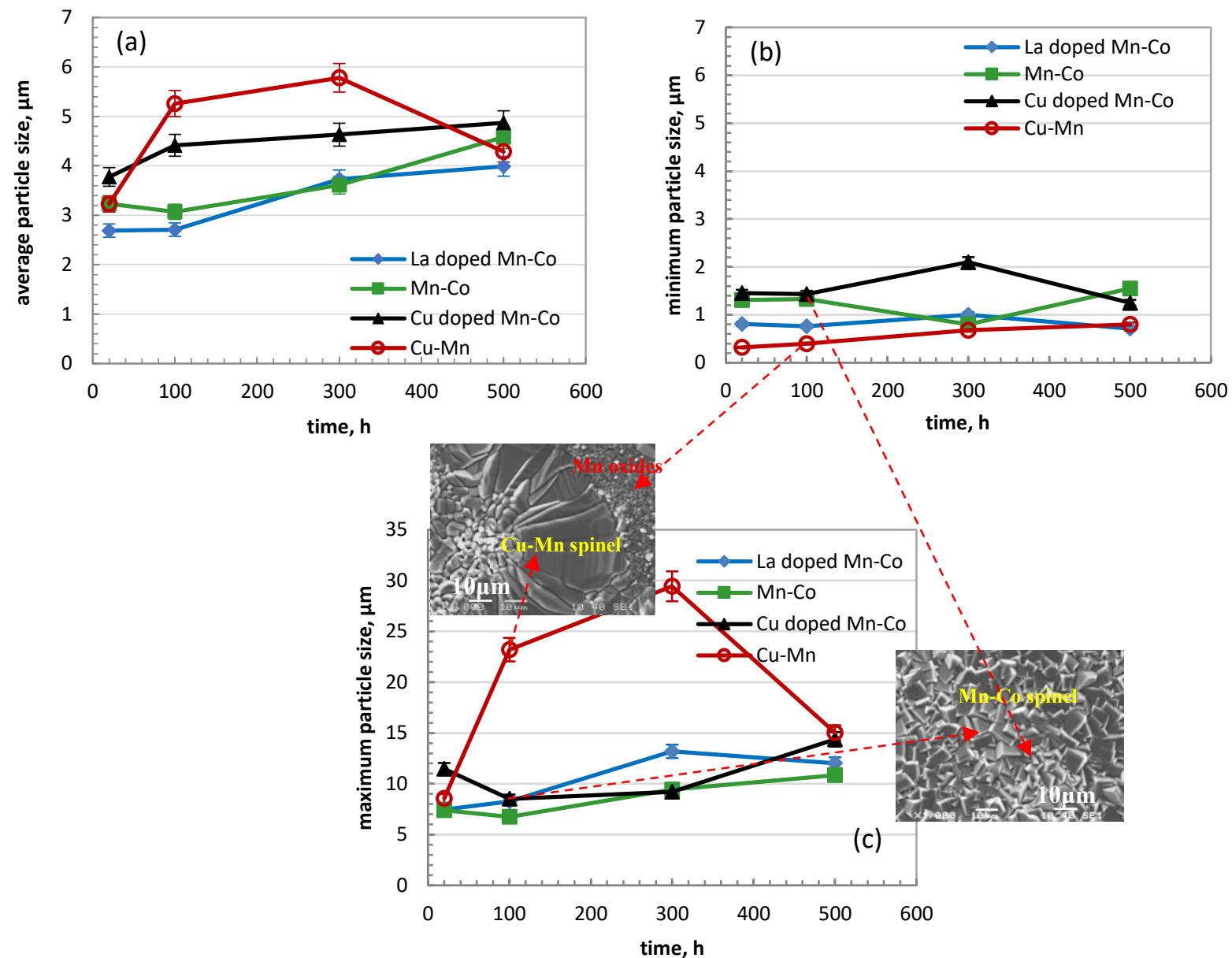

Fig.1 Particle sizes of spinel oxides on the surface for four alloy layers oxidized at $750^{\circ} \mathrm{C}$ in air. (a) average particle size (b) minimum particle size (c) maximum particle size 

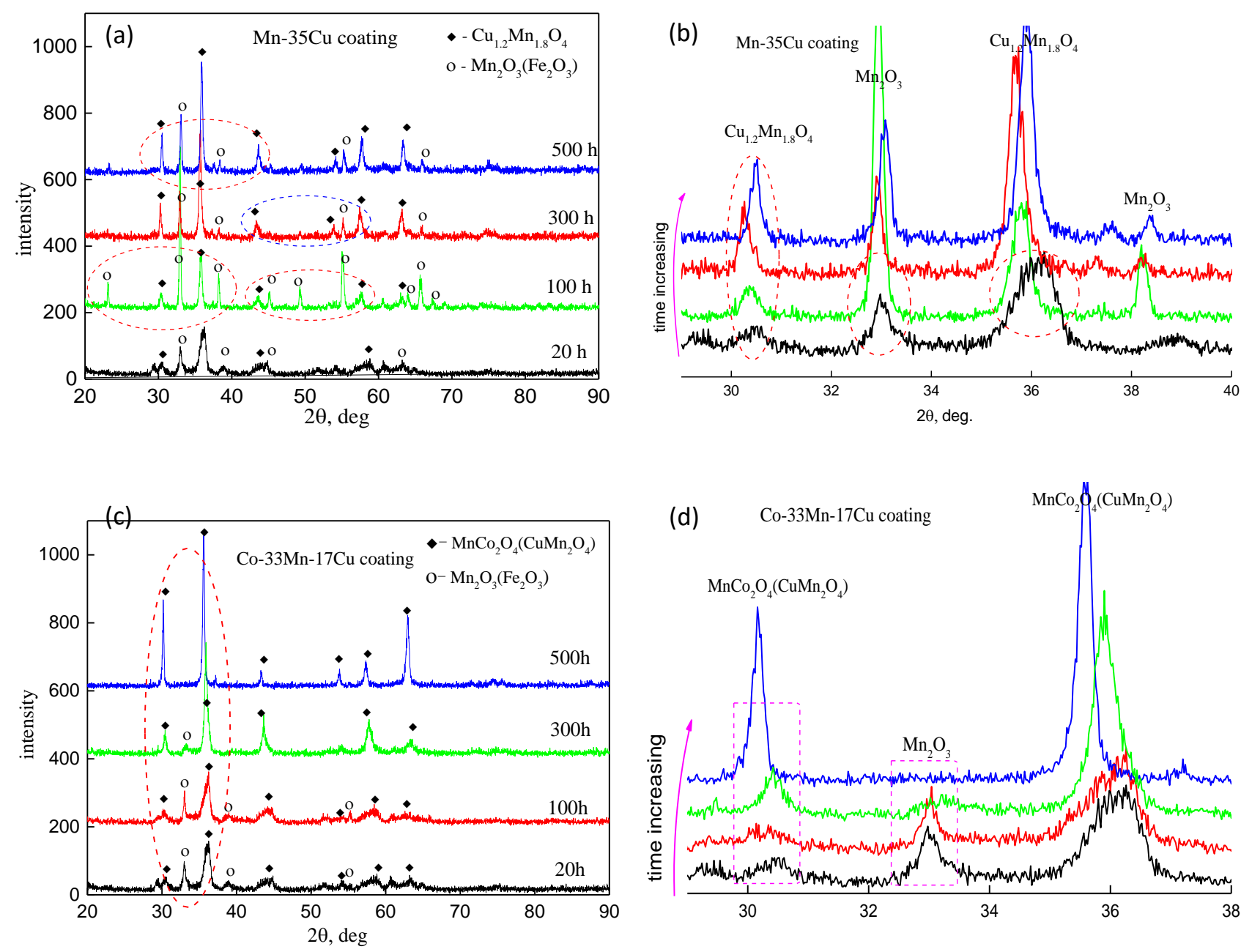

Fig.2 XRD patterns and partial XRD of (a) (b) Mn-35Cu and (c) (d) Cu doped Mn-Co alloy layers oxidized in air at $750{ }^{\circ} \mathrm{C}$ with the extended oxidation time 

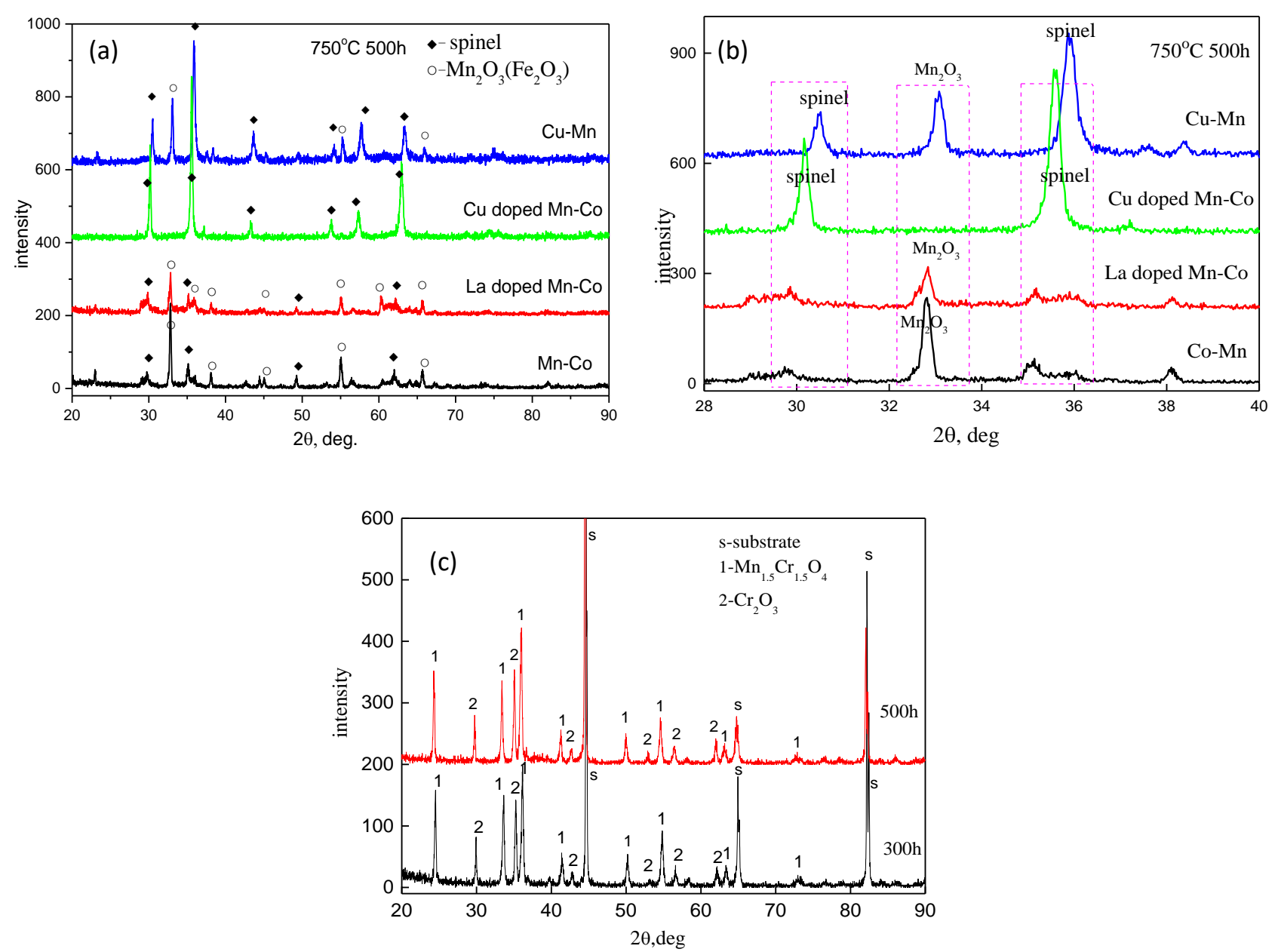

Fig.3 (a) (b) XRD patterns and partial XRD $\left(28^{\circ}-40^{\circ}\right)$ of four alloy layers after oxidation in air at $750^{\circ} \mathrm{C}$ for $500 \mathrm{~h}$ (c) XRD patterns of $430 \mathrm{SS}$ oxidized in air at $750^{\circ} \mathrm{C}$ for $300 \mathrm{~h}$ and $500 \mathrm{~h}$ 


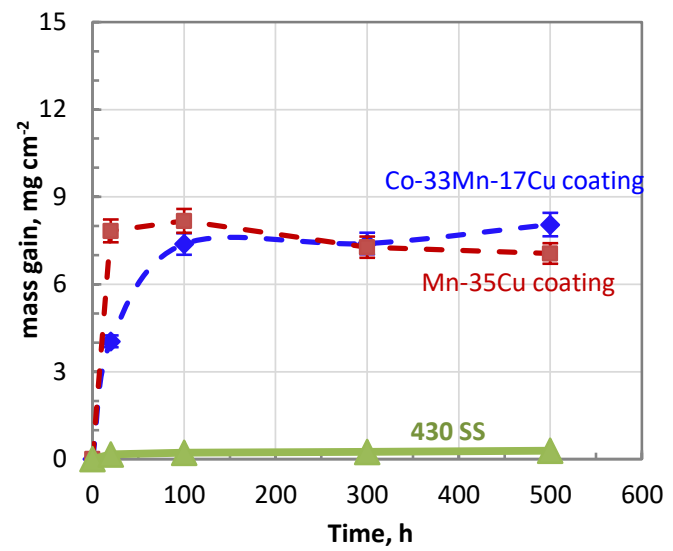

Fig.4 Oxidation kinetic curves of $\mathrm{Mn}-35 \mathrm{Cu}$ layer, $\mathrm{Co}-33 \mathrm{Mn}-17 \mathrm{Cu}$ layer and $430 \mathrm{SS}$ oxidized at $750{ }^{\circ} \mathrm{C}$ for $500 \mathrm{~h}$ in air 

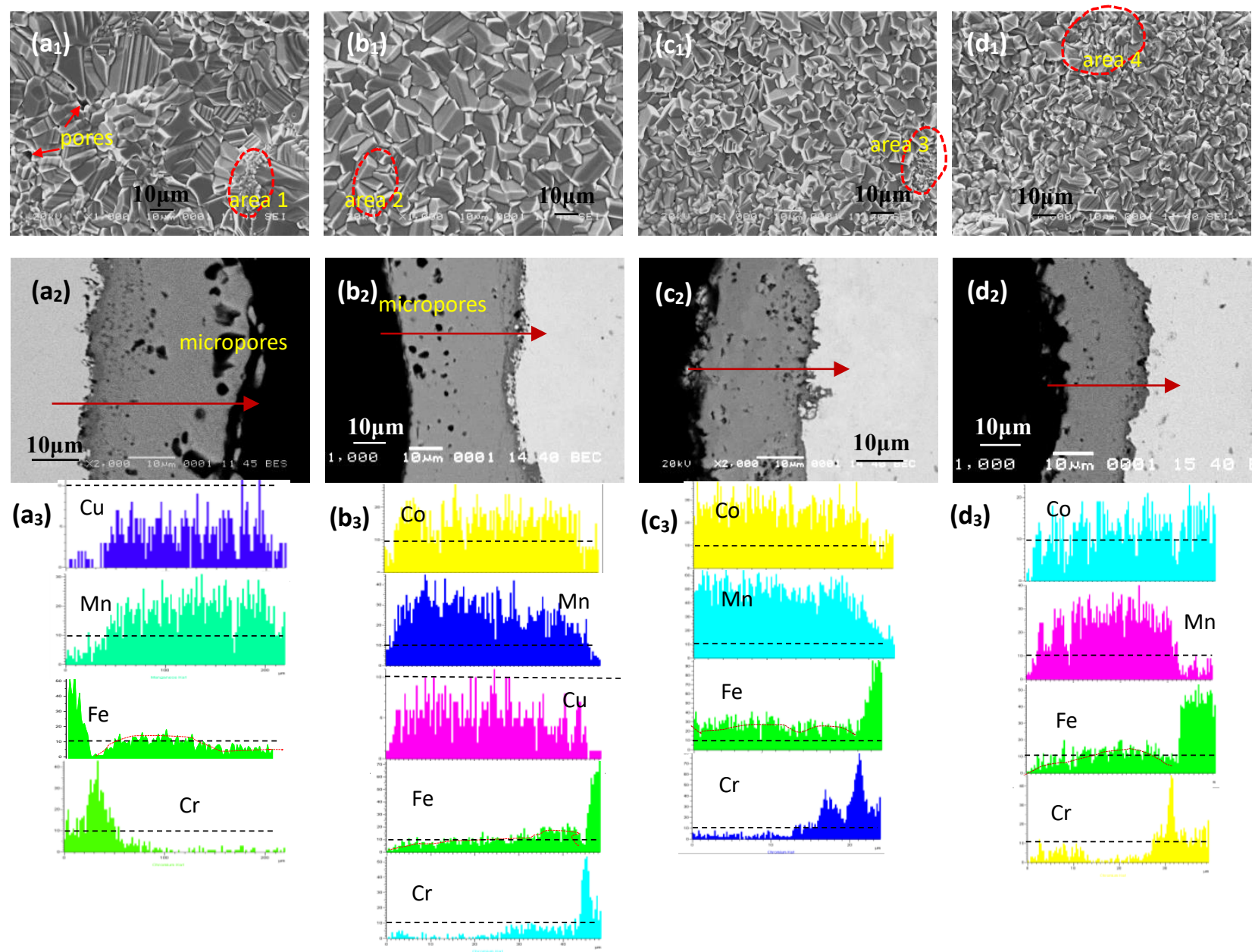

Fig. 5 Surface and cross-sectional morphology of oxide layers on $430 \mathrm{SS}$ after oxidation at $750^{\circ} \mathrm{C}$ for $500 \mathrm{~h}$ $\left(a_{1}\right)\left(a_{2}\right)\left(a_{3}\right)$ Mn-35Cu layer, $\left(b_{1}\right)\left(b_{2}\right)\left(b_{3}\right)$ Cu doped Mn-Co layer, $\left(c_{1}\right)\left(c_{2}\right)\left(c_{3}\right)$ La doped Mn-Co layer, $\left(d_{1}\right)\left(d_{2}\right)\left(d_{3}\right)$ Co-35Mn layer, $\left(a_{3}\right)\left(b_{3}\right)\left(c_{3}\right)\left(d_{3}\right)$ EDS line scanning of elements

Table 1 Element concentration (at.\%) on the surface of samples after oxidation at $750^{\circ} \mathrm{C}$ for $500 \mathrm{~h}$

\begin{tabular}{ccccccc}
\hline Alloy layers & Co & Mn & $\mathbf{C u}$ & Fe & Cr & O \\
\hline Mn-35Cu & - & 22.6 & 12.2 & 6.8 & - & 58.4 \\
Cu doped Mn-Co & 11.8 & 20.9 & 7.0 & 3.8 & - & 56.5 \\
La doped Mn-Co & 15.6 & 19.2 & - & 5.4 & - & 59.8 \\
Co-35Mn & 14.2 & 24.3 & - & 6.5 & - & 55.0 \\
\hline
\end{tabular}



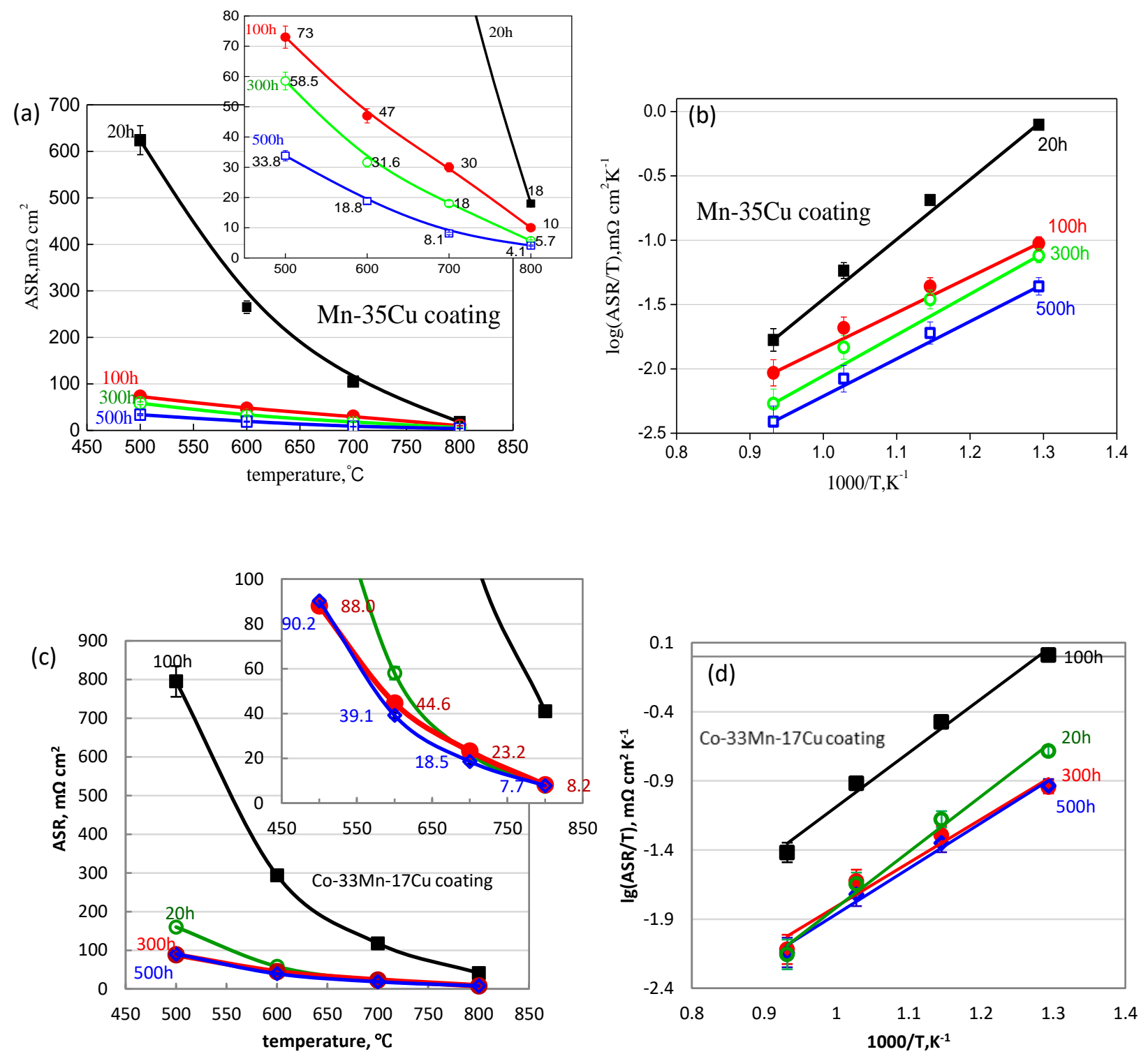

Fig.6 ASR values vs. temperature (a) (c) and Arrhenius plots of ASR/T vs. 103/T (b) (d) for $\mathrm{Mn}-35 \mathrm{Cu}$ and $\mathrm{Cu}$ doped Mn-Co layers oxidized in air at $750^{\circ} \mathrm{C}$ with the extended oxidation time 
(a)

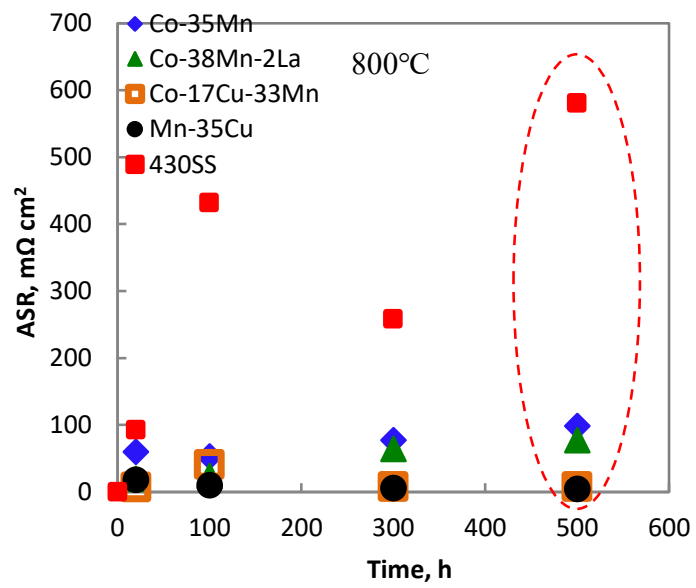

(b)

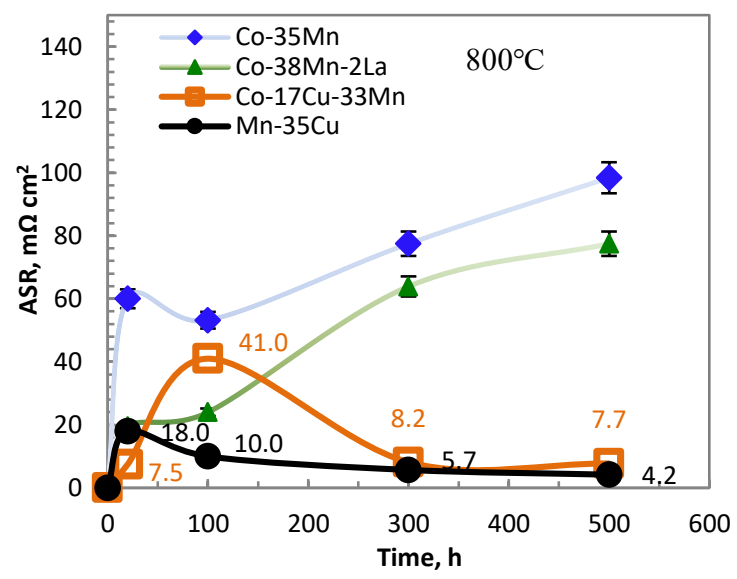

Fig.7 ASR values at $800^{\circ} \mathrm{C}$ vs. oxidation time for four oxide layers and bared $430 \mathrm{SS}$ after oxidation at $750^{\circ} \mathrm{C}$ 


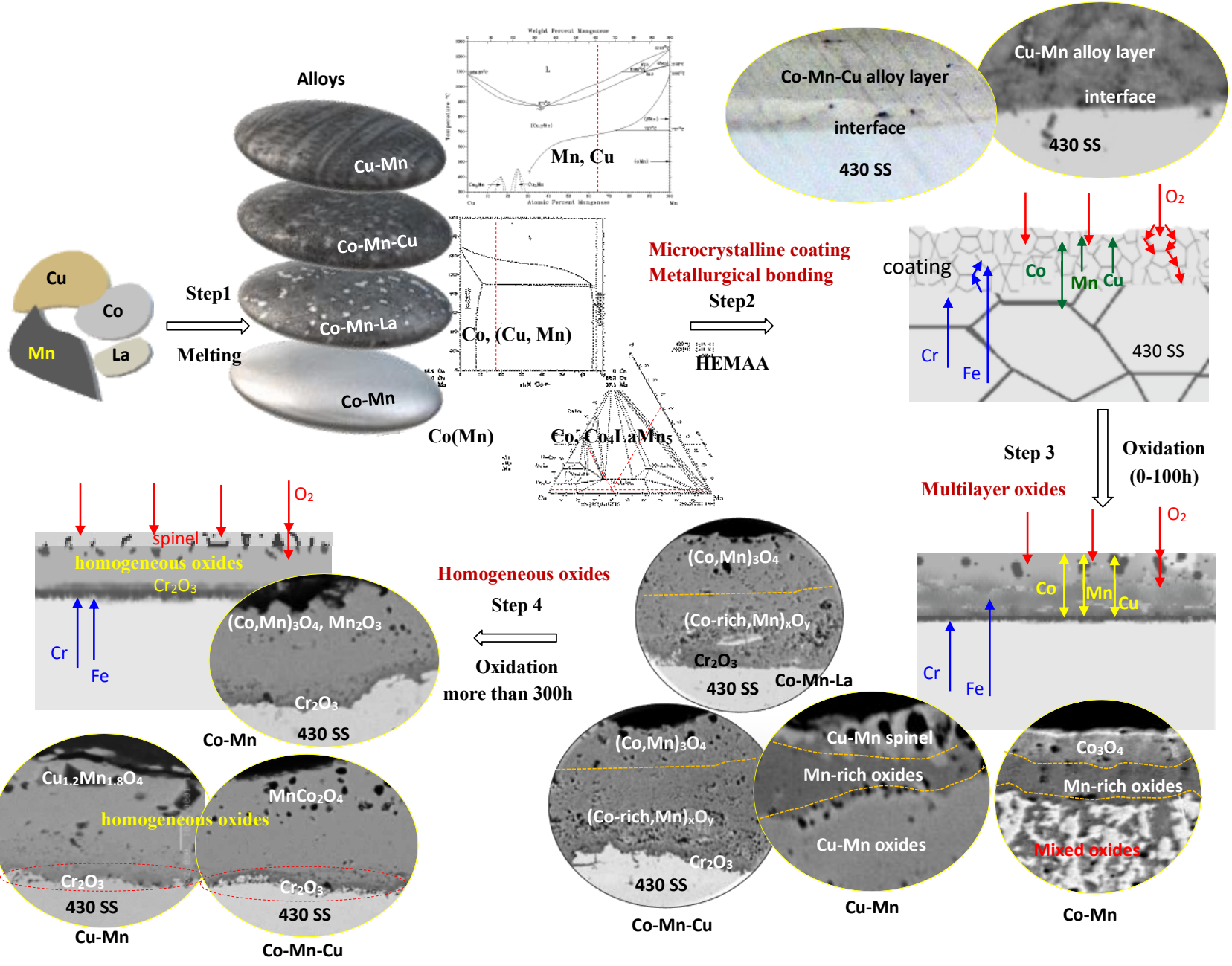

Fig. 8 Schematic diagrams of formation process for the homogeneous oxides prepared by high-energy micro-arc alloying process $[6,21,22]$ 